\title{
BENTUK SURAT KUASA MEMBEBANKAN HAK TANGGUNGAN SETELAH DIKELUARKANNYA PERATURAN KEPALA BADAN PERTANAHAN NASIONAL NOMOR 8 TAHUN 2012 TENTANG KETENTUAN PELAKSANA PERATURAN PEMERINTAH NOMOR 24 TAHUN 1997 TENTANG PENDAFTARAN TANAH
}

\author{
By : \\ Ni Putu Selvyana Putri Pratamikha*, Made Subawa**, \\ I Putu Tuni Cakabawa Landra*** \\ The Master's Program of Notary of the Udayana University \\ e-mail : selvyanapratamikha@yahoo.com
}

\begin{abstract}
The Power of Attorney of the Encumbrance Rights (SKMHT) is a special power of attorney which includes the power to impose the provision of encumbrance by the encumbrance grantor to the recipient of the encumbrance or other person authorized to it. The Power of Attorney of the Encumbrance Rights (SKMHT) must be made in two forms namely the notarial deed or the deed of the land deed official (PPAT) as stipulated by the provisions of Article 15 paragraph (1) of the Law Number 4 of 1996 on the Encumbrance Rights of the Land Along with Bodies Relating to Land. The enactment of the National Land Agency Regulation Number 8 of 2012 requires that the SKMHT shall be made in accordance with the format of the attachment of the Regulation. . While the SKMHT in the form of notarial deed shall be made in accordance with the provisions of Article 1868 of the Civil Code, the Article 38 of the Revised Law on the Position of the Land Deed Official (UUJNP), and the Article 15 of the Law on The Encumbrance Rights (UUHT). This results in the different arrangements resulting in the lack of uniformity of the SKMHT forms made by a notary or the land deed official (PPAT) which giving rise to the legal uncertainty of the form of the SKMHT and the legal effect of the SKMHT made in the form of a notarial deed.

The study is a normative legal research, intended to examine the differences in the SKMHT arrangement between the provisions of Article 15 paragraph (1) of The Encumbrance Rights (UUHT) with the Regulation of the Head of National Land Agency (Perkaban) Number 8 of 2012. The study uses the statutory approach that is supported by the literature, legal theory, the opinions of the scholars, as well as the legal dictionaries, as its legal materials.

The findings of the study show that the Regulation of the Head of National Land Agency (Perkaban) Number 8 of 2012 does not abolish the SKMHT in the form of a notarial deed as provided in Article 15 paragraph (1) of The Encumbrance Rights (UUHT). the SKMHT in the form of a notarial deed shall be made in accordance with the provisions of Article 1868 of the Civil Code, the Article 38 of the Revised Law on the Position of the Land Deed Official (UUJNP), and the Article 15 of the Law on The Encumbrance Rights (UUHT), while the SKMHT in the form of the land deed official (PPAT) shall be made in accordance with the provisions of the Regulation of the Head of National Land Agency (Perkaban) Number 8 of 2012 along with its attachments. It is expected that the firm provisions which regulate the SKMHT in the forms of the notarial deed should be enacted in order to create its legal certainty.
\end{abstract}

Keywords : The Power of Attorney of the Encumbrance Rights, the Notarial Deed, the deed of the land deed official (PPAT), the Regulation of the Head of National Land Agency (Perkaban) Number 8 of 2012.

\section{PENDAHULUAN}

\subsection{Latar Belakang}

Seiring dengan semakin berkembangnya kegiatan perekonomian maka kebutuhan masyarakat semakin banyak pula. Banyak masyarakat yang membutuhkan modal dalam pengembangan usaha maupun memenuhi kebutuhan hidupnya dengan membutuhkan pihak lain untuk memberikan pinjaman modal atau kredit. Pihak yang biasanya berperan dalam pemberian kredit adalah bank. Dalam prakteknya, 
bank selaku kreditur dalam memberikan fasilitas kredit meminta kepada debitur untuk menyerahkan jaminan berdasarkan persyaratanpersyaratan yang sebelumnya telah disepakati antara bank selaku kreditur dengan peminjam selaku debitur.

Pasal 8 UU Perbankan menentukan bahwa dalam memberikan kredit, bank wajib memiliki keyakinan terhadap debitur. Penjelasan Pasal 8 tersebut menegaskan bahwa untuk memperoleh keyakinan tersebut, pihak bank sebelum memberikan kredit harus melakukan penilaian yang seksama terhadap "The $5 \mathrm{C}$ ” yaitu character (karakter/watak), capacity (kemampuan), capital (modal), collateral (agunan), dan condition of economy (kondisi ekonomi nasabah). ${ }^{1}$

Jaminan diserahkan oleh debitur kepada kreditur dalam rangka pemberian fasilitas kredit dan merupakan unsur penilaian yang dilakukan oleh kreditur sebelum memberikan kredit kepada pihak yang memerlukannya. Hukum jaminan di Indonesia diatur dalam Buku II Kitab UndangUndang Hukum Perdata (selanjutnya disingkat KUHPerdata) dan Staatblad 1908 Nomor 542 dan telah diubah dengan Staatblad 1937 Nomor 190 Tentang Credietverband. ${ }^{2}$

Salah satu bentuk jaminan yang digunakan sebagai jaminan oleh debitur adalah tanah. Tanah sebagai jaminan kredit tunduk pada UUPA sebagai ketentuan dasar yang mengatur pertanahan nasional. Dengan berlakunya UUPA pada tanggal 24 September 1960, maka hak jaminan atas tanah disebut dengan hak tanggungan. Kemudian pada tanggal 9 April 1996 diundangkannya Undang-Undang Nomor 4 Tahun 1996 Tentang Hak Tanggungan Atas Tanah Beserta Benda-Benda Yang Berkaitan Dengan Tanah (selanjutnya disingkat UUHT) yang merupakan perwujudan ketentuan Pasal 51 UUPA

${ }^{1}$ Adrian Sutedi, 2010, Hukum Hak Tanggungan, PT. Sinar Grafika, Jakarta, hal. 97.

${ }^{2}$ Salim HS., 2001, Perkembangan Hukum Jaminan di Indonesia, Raja Grafindo Persada, Jakarta, hal. 1. sebagai ketentuan hukum mengenai hak tanggungan.

Tahap pemberian hak tanggungan didahului dengan janji akan memberikan hak tanggungan. Debitur sebagai pemberi hak tanggungan wajib hadir sendiri dihadapan Pejabat Pembuat Akta Tanah (selanjutnya disingkat PPAT), karena pembebanan hak tanggungan dilakukan oleh debitur sebagai subjek yang bertindak atas objek hak tanggungan.

Dalam perjanjian pemberian kredit, debitur yang tidak dapat hadir pada saat pemberian hak tanggungan dihadapan PPAT dapat membuat Surat Kuasa Membebankan Hak Tanggungan (selanjutnya disingkat SKMHT). SKMHT merupakan surat kuasa khusus yang dibuat dihadapan Notaris/PPAT yang mana debitur sebagai pemberi kuasa memberikan haknya kepada kreditur sebagai penerima kuasa untuk membebankan hak tanggungan pada objek jaminan berupa tanah. SKMHT wajib dibuat dalam 2 (dua) bentuk yaitu akta notaris atau akta PPAT sebagaimana dinyatakan dalam Pasal 15 ayat (1) UUHT.

Dalam rangka penyelenggaraan pendaftaran tanah sebagaimana diamanatkan oleh UUPA maka pada tanggal 8 Juli 1997 ditetapkan dan diundangkan Peraturan Pemerintah Nomor 24 Tahun 1997 tentang Pendaftaran Tanah (selanjutnya disebut PP Pendaftaran Tanah) menggantikan Peraturan Pemerintah Nomor 10 Tahun 1961 Tentang Pendaftaran Tanah yang sejak tahun 1961 mengatur pelaksanaan pendaftaran tanah sebagaimana yang diperintahkan oleh Pasal 19 UUPA. ${ }^{3}$ Diundangkannya PP Pendaftaran Tanah yang baru ini kemudian mulai berlaku 3 bulan sejak diundangkannya, maka Peraturan Pemerintah

${ }^{3}$ Budi Harsono, 2008, Hukum Agraria Indonesia, Sejarah Pembentukan Undang-Undang Pokok Agraria, Isi dan Pelaksanaannya Jilid 1 Hukum Tanah Nasional, Djambatan, Jakarta, hal. 469. 
Nomor 10 Tahun 1961 Tentang Pendaftaran Tanah dinyatakan tidak berlaku lagi.

Kepala Badan Pertanahan Nasional Republik Indonesia pada tanggal 1 Oktober 1997 mengeluarkan Peraturan Menteri Agraria/Kepala Badan Pertanahan Nasional Nomor 3 Tahun 1997 sebagai ketentuan pelaksana PP Nomor 24 Tahun 1997 tentang Pendaftaran Tanah (selanjutnya disebut Perkaban 3/1997). Peraturan ini mengatur mengenai pelaksanaan kegiatan pendaftaran tanah nasional dan setiap kegiatan pendaftaran tanah harus dan wajib tunduk pada ketentuan yang diatur didalam peraturan tersebut.

Pada tanggal 27 Desember 2012, Badan Pertanahan Nasional mengeluarkan Peraturan Kepala Badan Pertanahan Nasional Nomor 8 Tahun 2012 Tentang Perubahan Atas Peraturan Kepala Badan Pertanahan Nasional Nomor 3 Tahun 1997 Tentang Ketentuan Pelaksanaan Peraturan Pemerintah Nomor 24 Tahun 1997 Tentang Pendaftaran Tanah (selanjutnya disingkat Perkaban 8/2012). Dikeluarkannya Perkaban 8/2012 ini mengakibatkan ketentuan-ketentuan pelaksana kegiatan pendaftaran tanah sepanjang belum diatur dalam Perkaban 8/2012 ini maka ketentuan Perkaban 3/1997 masih tetap berlaku.

Perkaban 8/2012 mengatur mengenai tata cara pembuatan akta PPAT yang awalnya menggunakan blangko PPAT yang diperoleh dari Kantor Badan Pertanahan Nasional menjadi setiap akta PPAT dibuat oleh masing-masing PPAT dengan ketentuan bentuk dan format akta yang ditentukan baku oleh Perkaban 8/2012. Salah satu bentuk akta PPAT yang diatur dalam Perkaban 8/2012 adalah Surat Kuasa Membebankan Hak Tanggungan.

Ketentuan hukum yang diatur dalam Perkaban 8/2012 yang merupakan peraturan pelaksana dari Peraturan Pemerintah Nomor 24 Tahun 1997 sebagai peraturan pelaksana UUHT. Berlakunya Perkaban 8/2012 yang menentukan bentuk SKMHT wajib dibuat berdasarkan format dan bentuk akta dalam lampiran Perkaban sedangkan Pasal 15 ayat (1) UUHT menentukan bahwa SKMHT dapat dibuat dalam bentuk akta notaris atau akta PPAT.. Pelaksanaan pembuatan SKMHT berdasarkan Pasal 15 ayat (1) UUHT dan Perkaban 8/2012 tersebut menimbulkan ketidakseragaman sehingga terjadi ketidakpastian hukum mengenai bentuk SKMHT yang digunakan sebagai surat kuasa untuk membebankan hak tanggungan.

Bentuk SKMHT yang dibuat oleh Notaris/PPAT setelah dikeluarkannya Perkaban 8/2012 dibuat dengan berbagai bentuk akta notaris dan akta PPAT. Beberapa Notaris menggunakan format akta notaris untuk SKMHT yang tanahnya berada pada wilayah jabatan Notaris. Namun, beberapa Notaris menggunakan format SKMHT sesuai dengan lampiran Perkaban 8/2012 untuk tanah yang berada pada wilayah jabatan Notaris. Perbedaan pengaturan yang mengakibatkan ketidakseragaman bentuk SKMHT tersebut diatas menurut hemat penulis sangat penting kedepannya untuk menyumbang ilmu pengetahuan bagi pihak-pihak baik Notaris/PPAT maupun Badan Pertanahan Nasional serta pihak-pihak yang berkaitan dengan SKMHT

\subsection{Rumusan Masalah}

1. Apakah Peraturan Kepala Badan Pertanahan Nasional Nomor 8 Tahun 2012 Tentang Ketentuan Pelaksanaan Peraturan Pemerintah Nomor 24 Tahun 1997 Tentang Pendaftaran Tanah yang mewajibkan Surat Kuasa Membebankan Hak Tanggungan dibuat dalam bentuk Akta PPAT khusus yang ditentukan dalam peraturan ini meniadakan bentuk Surat Kuasa Membebankan Hak Tanggungan dalam bentuk akta notaris sebagaimana yang diatur dalam Pasal 15 ayat (1) UUHT ?

2. Bagaimana akibat hukum yang timbul apabila Surat Kuasa Membebankan Hak Tanggungan dibuat dalam bentuk akta notaris setelah 
dikeluarkannya Peraturan Kepala Badan

Pertanahan Nasional Nomor 8 Tahun 2012

Tentang Ketentuan Pelaksanaan Peraturan

Pemerintah Nomor 24 Tahun 1997 Tentang

Pendaftaran Tanah?

\subsection{Landasan Teori}

\subsubsection{Teori Negara Hukum}

Teori negara hukum bermula dari pemikiran Plato yang menyatakan bahwa penyelenggaraan negara yang baik ialah yang didasarkan pada pengaturan (hukum) yang baik yang disebut dengan istilah "nomoi". 4 Berdasarkan teori negara hukum tersebut, khususnya mengenai legalitas, maka apabila dikaitkan dengan permasalahan ini diperlukan adanya ketegasan dan kepastian hukum yang tidak bertentangan satu sama lain antara ketentuan Perkaban 8/2012 dengan ketentuan Pasal 15 ayat (1) UUHT yang mengatur mengenai bentuk Surat Kuasa Membebankan Hak Tanggungan. Teori ini berguna untuk memberikan kepastian hukum mengenai bentuk Surat Kuasa Membebankan Hak Tanggunan setelah dikeluarkannya Perkaban 8/2012 dikarenakan Indonesia merupakan suatu negara hukum.

\subsubsection{Teori Kepastian Hukum atau Teori Normatif Dogmatif}

Teori ini dicetuskan oleh John Austin dan Van Kan yang menyatakan bahwa tujuan hukum adalah semata-mata untuk menciptakan kepastian hukum. Arti kepastian hukum disini adalah menjaga setiap kepentingan subjek hukum agar tidak terganggu dan terjamin kepastiannya. ${ }^{5}$ Teori kepastian hukum atau teori normatif dogmatif ini digunakan untuk menjamin kepastian hukum atas pertentangan norma mengenai bentuk SKMHT yang terjadi antara Pasal 15 ayat (1) UUHT

${ }^{4}$ Titik Triwulan Tutik, 2011, Kontruksi Hukum Tata Negara Indonesia Pasca Amandemen UUD 1945, Kencana Prenada Media Group, Jakarta, hal. 61

${ }^{5}$ Eugenius Sumaryono, 1987, Filsafat Hukum Sebuah Pengantar Singkat, Universitas Atmajaya Yogyakarta, Yogyakarta, hal. 53 dengan ketentuan Perkaban 8/2012. Bentuk SKMHT yang ditentukan dalam Pasal 15 ayat (1) UUHT dapat dibuat dalam bentuk akta notaris atau akta PPAT. Ketentuan Perkaban 8/2012 mewajibkan SKMHT dibuat dalam bentuk akta PPAT khusus. Bentuk akta tersebut ditentukan dalam lampiran peraturan yang bersangkutan dan pendaftaran perubahan data pendaftaran tanah serta pembuatan Akta Pemberian Hak Tanggungan tidak dapat dilakukan apabila pembuatan SKMHT tidak sesuai dengan ketentuan Perkaban 8/2012 tersebut.

\subsubsection{Teori Utilitas}

Teori ini dicetuskan oleh Jeremy Bentham yang bermakna bahwa tujuan hukum adalah untuk menjamin kebahagiaan yang terbesar bagi manusia dalam jumlah yang sebanyak-banyaknya (the greatest good of the greatest number). Pada hakikatnya hukum dimanfaatkan untuk menghasilkan sebesar-besarnya kesenangan atau kebahagiaan bagi orang banyak. $^{6}$ Teori ini berguna untuk mewujudkan kepastian hukum mengenai bentuk SKMHT setelah dikeluarkannya Perkaban 8/2012 sehingga akan berguna dan bermanfaat dalam pembuatan SKMHT dengan suatu bentuk tertentu bagi Notaris/PPAT dan pihak-pihak yang terkait.

\subsubsection{Teori Penjenjangan Norma}

Teori ini dikemukakan oleh Hans Kelsen yang menyatakan bahwa hubungan norma-norma digambarkan sebagai sistem bangunan piramidal. Hukum tumbuh dan berkembang dari norma yang lebih tinggi, yang lebih abstrak dan hanya memberi norma kepada norma lain yang tingkatannya lebih rendah. ${ }^{7}$ Asas penjenjangan norma yang digunakan dalam tesis ini adalah asas lex superiori derogate legi inferior. Asas ini mengandung pengertian the higher statute prepail over the lower statute yaitu peraturan perundangundangan yang lebih tinggi mengalahkan peraturan perundang-undangan yang lebih rendah.

${ }^{6}$ Ibid, hal. 56.

${ }^{7}$ Ibid, hal. 49. 


\subsection{Tujuan Penelitian}

\subsubsection{Tujuan Umum}

Adapun tujuan umum penulisan ini adalah untuk mengembangkan ilmu hukum, terutama dalam bidang Hukum Kenotariatan terkait dengan bentuk SKMHT dan akibat hukum yang timbul apabila SKMHT dibuat dalam bentuk akta notaris setelah dikeluarkannya Perkaban 8/2012. Penelitian ini juga bertujuan untuk mengembangkan ilmu hukum, khususnya dibidang hukum kenotariatan serta sebagai syarat untuk menyelesaikan jenjang pendidikan strata dua (2) di Magister Kenotariatan Universitas Udayana.

\subsubsection{Tujuan Khusus}

Penulisan ini bertujuan khusus untuk mengetahui dan menganalisis bentuk Surat Kuasa Membebankan Hak Tanggungan setelah dikeluarkannya Perkaban 8/2012. Apabila telah diketahui dan dianalisis, maka selanjutnya dianalisis akibat hukum yang timbul terhadap Surat Kuasa Membebankan Hak Tanggungan yang dibuat dalam bentuk akta notaris setelah dikeluarkannya Perkaban 8/2012.

\section{METODE PENELITIAN}

\subsection{Jenis Penelitian}

Jenis penelitian yang digunakan dalam penelitian tesis ini adalah penelitian hukum normatif. Hal ini terkait dengan perbedaan pengaturan mengenai bentuk SKMHT antara Pasal 15 ayat (1) UUHT yang menentukan SKMHT wajib dibuat dalam bentuk akta notaris atau akta PPAT dengan Perkaban 8/2012 yang menentukan SKMHT wajib dibuat sesuai dengan ketentuan format dan bentuk akta dalam lampiran perkaban tersebut sehingga mengakibatkan ketidakseragaman bentuk SKMHT yang dibuat oleh notaris/PPAT.

\subsection{Jenis Pendekatan}

Penulis menggunakan dua jenis pendekatan untuk menganalisis permasalahan yang ada. Pendekatan hukum tersebut yaitu Pendekatan
Peraturan Perundang-undangan (Statute Approach) yang menyelaraskan Pasal 15 ayat (1) UUHT dengan Perkaban 8/2012 dan Pendekatan Konseptual (Conceptual Approach) untuk menganalisa konsep-konsep yang relevan dalam penelitian ini yang dapat ditemukan dalam pandangan-pandangan para sarjana atau doktrindoktrin hukum sehingga memperoleh hasil yang ingin dicapai. ${ }^{8}$

\subsection{Sumber Bahan Hukum}

Sumber bahan hukum digunakan oleh penulis untuk mengkaji dan membahas permasalahan dalam penelitian ini. Sumber bahan hukum yang digunakan antara lain:

1. Bahan hukum primer yaitu bahan hukum yang mempunyai kekuatan mengikat, berupa peraturan perundangundangan, yurisprudensi serta perjanjian internasional. ${ }^{9}$ Bahan hukum primer yang digunakan dalam penelitian ini antara lain:

- Undang-Undang Dasar Negara

Republik Indonesia Tahun 1945;

- Kitab Undang-Undang Hukum

Perdata;

- Undang-Undang Negara Republik

Indonesia Nomor 5 Tahun 1960

Tentang Peraturan Dasar Pokok-

Pokok Agraria (Lembaran Negara

Republik Indonesia Tahun 1960

Nomor 104 dan Tambahan

Lembaran Negara Republik

Indonesia Nomor 2043);

- Undang-Undang Negara Republik

Indonesia Nomor 4 Tahun 1996

Tentang Hak Tanggungan Atas

Tanah Beserta Benda-Benda Yang

Berkaitan Dengan Tanah

(Lembaran Negara Republik

${ }^{8}$ Peter Mahmud Marzuki, 2006, Penelitian Hukum, Kencana Prenada Media Group, Jakarta, hal. 94.

${ }^{9}$ Amiruddin dan H. Zainal Asikin, 2008, Pengantar Metode Penelitian Hukum, PT. Raja Grafindo Persada, Jakarta, hal. 118. 
Indonesia Tahun 1996 Nomor 42 dan Tambahan Lembaran Negara Republik Indonesia Nomor 3632);

- Undang-Undang Nomor 10 Tahun 1998 Tentang Perubahan Atas Undang-Undang Nomor 7 Tahun 1992 Tentang Perbankan (Lembaran Negara Republik Indonesia Tahun 1998 Nomor 182 dan Tambahan Lembaran Negara Republik Indonesia Nomor 3790);

- Undang-Undang Negara Republik Indonesia Nomor 30 Tahun 2004 Tentang Jabatan Notaris (Lembaran Negara Republik Indonesia Tahun 2004 Nomor 117 dan Tambahan Lembaran Negara Republik Indonesia Nomor 4432);

- Undang-Undang Negara Republik Indonesia Nomor 2 Tahun 2014 Tentang Perubahan Atas UndangUndang Nomor 30 Tahun 2004 Tentang Jabatan Notaris (Lembaran Negara Republik Indonesia Tahun 2014 Nomor 3 dan Tambahan Lembaran Negara Republik Indonesia Nomor 5491);

- Peraturan Pemerintah Republik Indonesia Nomor 24 Tahun 1997 Tentang Pendaftaran Tanah (Lembaran Negara Republik Indonesia Tahun 1997 Nomor 59 dan Tambahan Lembaran Negara Republik Indonesia Nomor 3696);

- Peraturan Pemerintah Republik Indonesia Nomor 37 Tahun 1998 Tentang Peraturan Jabatan Pembuat Akta Tanah (Lembaran Negara Republik Indonesia Tahun 1998 Nomor 52 dan Tambahan Lembaran Negara Republik Indonesia Nomor 3746);
- Peraturan Menteri Negara Agraria/Kepala Badan Pertanahan Nasional Nomor 4 Tahun 1996 Tentang Penetapan Batas Waktu Penggunaan Surat Kuasa Membebankan Hak Tanggungan Untuk Menjamin Pelunasan Kredit-Kredit Tertentu;

- Peraturan Kepala Badan Pertanahan Nasional Nomor 3 Tahun 1997 Tentang Ketentuan Pelaksanaan Peraturan Pemerintah Nomor 24 Tahun 1997 Tentang Pendaftaran Tanah;

- Peraturan Kepala Badan Pertanahan Nasional Nomor 8 Tahun 2012 perubahan atas Peraturan Kepala Badan Pertanahan Nasional Nomor 3 Tahun 1997 Tentang Ketentuan Pelaksanaan Peraturan Pemerintah Nomor 24 Tahun 1997 Tentang Pendaftaran Tanah;

- Surat Keputusan Direksi Bank Indonesia Nomor 26/24/KEP/DIR tertanggal 29 Mei 1993

2. Bahan hukum sekunder, yaitu bahan hukum penunjang berupa teori-teori hukum dan pendapat para sarjana. ${ }^{10}$ Bahan hukum sekunder yang digunakan dalam penelitian ini yaitu buku-buku mengenai jabatan notaris/PPAT, perjanjian, kuasa, hak tanggungan, SKMHT maupun bukubuku lain yang berkaitan, hasil-hasil penelitian yang relevan, perndapat pakar hukum, dan artikel terkait.

3. Bahan hukum tertier, yaitu bahan hukum yang dapat memberikan penjelasan terhadap bahan hukum primer maupun bahan hukum sekunder. Bahan hukum tertier dalam penelitian ini berupa kamus

${ }^{10}$ Peter Mahmud Marzuki, Op.cit, hal.141. 
hukum, ensiklopedia, dan kamus besar bahasa indonesia.

\subsection{Teknik Pengumpulan Bahan Hukum}

Teknik pengumpulan bahan hukum dalam penelitian ini adalah studi kepustakaan, yaitu mengumpulkan semua bahan hukum yang terkait untuk memperoleh data yang objektif dan akurat, baik dari buku-buku maupun dari internet yang berkaitan dengan permasalahan yang akan di bahas dalam penelitian ini. Teknik pengumpulan bahan hukum dalam penelitian ini juga menggunakan sistem kartu (card system). Secara teoritis, bahan hukum dalam penelitian dapat dikumpulkan dengan menggunakan sistem kartu (card system). ${ }^{11}$

\subsection{Teknik Analisis Bahan Hukum}

Teknik analisis bahan hukum yang digunakan dalam penelitian ini yaitu teknik deskripsi, teknik interpretasi sistematisasi, teknik evaluasi, dan teknik argumentasi. Teknik deskripsi dilakukan dengan menguraikan dan menghubungkan teoriteori atau literatur-literatur yang berhubungan dengan permasalahan, dan akhirnya menarik suatu kesimpulan dalam bentuk argumentasi hukum untuk menemukan hasil dari penelitian. ${ }^{12}$ Kemudian teknik interpretasi (penafsiran) yang digunakan dalam penelitian ini adalah interpretasi sistematisasi yaitu proses pencarian kaitan antara peraturan perundang-undangan yang satu dengan peraturan perundang-undangan lain yang saling bergantungan khususnya mengenai bentuk SKMHT dan akibat hukum yang timbul apabila SKMHT dibuat dalam bentuk akta notaris setelah dikeluarkannya Perkaban 8/2012. Selanjutnya teknik evaluasi digunakan untuk menilai tepat atau tidaknya pernyataan rumusan norma yang mengatur mengenai bentuk SKMHT yang diatur dalam Perkaban 8/2012 dengan Pasal 15 ayat (1) UUHT. Hasil yang diperoleh disimpulkan dengan

${ }^{11}$ Winarno Surakhmad, 1972, $\underline{\text { Pengantar }}$ Penelitian Ilmiah, Dasar Metode dan Teknik, Tarsito, Bandung, hal. 257.

${ }^{12}$ Zainuddin Ali, 2010, Metode Penelitian Hukum, Sinar Grafika Offset, Jakarta, hal. 47. menggunakan teknik argumentasi berupa argumentasi hukum yang dikaitkan dengan penalaran hukum atas permasalahan yang dibahas dan bahan-bahan hukum yang diperoleh.

\section{TINJAUAN UMUM}

\subsection{Tinjauan Umum Tentang Akta}

Akta merupakan suatu pernyataan tertulis yang ditandatangani, dibuat oleh seseorang atau oleh pihak-pihak dengan maksud dapat dipergunakan sebagai alat bukti dalam proses hukum. ${ }^{13}$ Menurut $\mathrm{S}$. J. Fockema Andreae dalam bukunya yang berjudul "Rechts geleerd Handwoorddenboek", akta berasal dari bahasa latin yaitu acta yang berarti geschrift atau yang disebut juga dengan surat. ${ }^{14}$ Berdasarkan pengertian-pengertian tersebut maka dapat disimpulkan bahwa yang dimaksud dengan akta adalah : ${ }^{15}$

a. Perbuatan handeling perbuatan hukum (rechtshandeling) dalam perngertian yang luas, dan ;

b. Suatu tulisan yang dibuat untuk dipakai/digunakan sebagai bukti perbuatan hukum tersebut, yaitu berupa tulisan yang ditujukan kepada pembuktian sesuatu.

Tidaklah semua surat dapat disebut sebagai akta melainkan hanya suratsurat tertentu yang memenuhi syaratsyarat tertentu pula baru dapat disebut sebagai akta. Syarat-syarat tersebut adalah surat itu harus ditandatangani,

${ }^{13}$ I.G. Rai Widjaya, 2002, Merancang Suatu Kontrak Contract Drafting, Kesaint Blanc, Bekasi Timur, hal. 9.

${ }^{14} \mathrm{~S}$. J. Fockema Andreae, 1951, Rechtsgeleerd Handwoorddenboek, diterjemahkan oleh Walter Siregar, Bij J. B. Wolter uitgeversmaat schappij, N. V. Gronogen, Jakarta, hal. 9.

${ }^{15}$ M. Isa Arif, 1978, Pembuktian \& Daluwarsa, Intermasa, Jakarta, hal. 52. 
surat itu harus memuat peristiwa yang menjadi dasar sesuatu hak atau perikatan, dan surat itu diperuntukan sebagai alat bukti. ${ }^{16}$

Pasal $1867 \quad$ KUHPerdata
menyatakan bahwa "pembuktian dengan tulisan dilakukan dengan tulisan (akta) otentik maupun dengan tulisan-tulisan (akta) dibawah tangan. Akta dapat dibedakan menjadi 2 macam akta, yaitu akta dibawah tangan dan akta otentik. Akta dibawah tangan adalah akta yang dibuat tidak oleh atau tanpa perantaraan seorang pejabat umum, melainkan dibuat dan ditandatangani sendiri oleh para pihak yang mengadakan perjanjian. ${ }^{17}$ Kekuatan pembuktian akta dibawah tangan tidak sesempurna kekuatan pembuktian akta otentik. Sedangkan akta otentik adalah suatu akta yang bentuknya ditentukan oleh undang-undang, dibuat oleh atau dihadapan pejabat umum yang berwenang untuk itu ditempat dimana akta itu dibuatnya. ${ }^{18}$ Akta otentik memiliki kekuatan pembuktian sempurna.

Akta notaris diatur dalam Pasal 1 angka (7) UUJNP yang menentukan "akta notaris yang selanjutnya disebut akta adalah akta otentik yang dibuat oleh atau dihadapan notaris menurut bentuk dan tata cara yang ditetapkan dalam Undang-Undang ini." Selanjutnya akta notaris sebagai akta otentik wajib pula memenuhi ketentuan Pasal 38 UUJNP. Sedangkan akta PPAT tidak

${ }^{16}$ Sudikno Mertokusumo, 1979, $\underline{\text { Hukum }}$ Acara Perdata di Indonesia, Liberty, Yogyakarta, hal. 106.

${ }^{17}$ Santia Dewi dan R.M. Fauwas Diradja, 2011, Panduan Teori \& Praktik Notaris, Pustaka Yustisia, Yogyakarta, hal. 36.

${ }^{18}$ Ibid, hal. 7 dinyatakan secara tegas pengertiannya dalam peraturan perundangan-undangan. Berdasarkan Pasal 1 angka (1) PP No. 37 Tahun 1998 Tentang PPAT, "PPAT adalah Pejabat Umum yang diberi kewenangan untuk membuat akta-akta otentik mengenai perbuatan hukum tertentu mengenai hak atas tanah atau hak milik atas satuan rumah susun."

\subsection{Tinjauan Umum Tentang SKMHT}

SKMHT adalah akta pemberian kuasa khusus untuk membuat APHT. ${ }^{19}$ Menurut Penjelasan Umum angka (7) UUHT, pada asasnya APHT wajib ditandatangani oleh pemberi hak tanggungan, namun apabila karena suatu sebab yang menyebabkan ia tidak bias hadir untuk menandatangani APHT maka ia wajib menunjuk pihak lain sebagai kuasanya dengan SKMHT yang berbentuk akta otentik. SKMHT wajib dibuat dengan akta notaris atau akta PPAT dan memenuhi persyaratan sebagai berikut :

a. Tidak memuat kuasa untuk melakukan perbuatan hukum lain daripada membebankan hak tanggungan;

b. Tidak memuat kuasa substitusi;

c. Mencantumkan secara jelas objek hak tanggungan, jumlah utang dan nama serta identitas krediturnya, nama dan identitas debitur apabila debitur bukan pemberi hak tanggungan.

SKMHT wajib dibuat dalam dua bentuk yaitu akta notaris dan akta PPAT sesuai ketentuan Pasal 15 ayat (1) UUHT. Berlakunya Perkaban 8/2012 mengatur mengenai bentuk SKMHT

${ }^{19}$ Mustofa, 2010, Tuntutan Pembuatan AktaAkta PPAT, Karya Media, Yogyakarta, hal. 247. 
yang wajib dibuat sesuai dengan lampiran Perkaban tersebut. SKMHT yang dibuat tidak dapat bentuk dan format yang ditetapkan dalam lampiran peraturan ini ditolak dan tidak dapat digunakan dalam hal pendaftaran di Badan Pertanahan Nasional.

II. BENTUK SURAT KUASA MEMBEBANKAN HAK TANGGUNGAN SETELAH DIKELUARKANNYA PERATURAN KEPALA BADAN PERTANAHAN NASIONAL NOMOR 8 TAHUN 2012 TENTANG KETENTUAN PELAKSANAAN PERATURAN PEMERINTAH NOMOR 24 TAHUN 1997 TENTANG PENDAFTARAN TANAH

\subsection{Otentisitas Surat Kuasa Membebankan} Hak Tanggungan

Pasal 15 ayat (1) UUHT menegaskan bahwa SKMHT wajib dibuat dengan akta notaris atau akta PPAT. Berkaitan dengan hal tersebut, bentuk SKMHT ditentukan pula dalam Pasal I Perkaban 8/2012 yang menegaskan bentuk akta yang dipergunakan di dalam pembuatan akta sebagaimana dimaksud dalam Pasal 95 ayat (1) dan ayat (2) dan tata cara pengisian dibuat sesuai dengan Lampiran Peraturan tersebut. Dengan demikian, kewenangan untuk membuat SKMHT ada pada notaris dan PPAT. Selanjutnya ketentuan Pasal 15 ayat (1) UUJN menegaskan bahwa notaris mempunyai kewenangan untuk membuat akta dan syarat serta ketentuan akta notaris berdasarkan ketentuan Pasal 38 UUJN. $^{20}$ SKMHT yang dibuat dalam bentuk akta notaris, selain wajib dibuat berdasarkan Perkaban 8/2012 tersebut juga wajib tunduk pada ketentuan UUJN

${ }^{20}$ Habib Adjie, 2009, Meneropong Khazanah Notaris dan PPAT Indonesia (Kumpulan Tulisan Tentang Notaris dan PPAT), PT. Citra Aditya Bakti, Bandung, hal. 31. jo UUJNP serta peraturan perundangundangan lain seperti Pasal 1868 KUHPerdata agar SKMHT dapat dinyatakan sebagai akta otentik. Keotentikan suatu akta notaris didasari oleh Pasal 1868 KUHPerdata dengan syarat-syarat sebagai berikut $:^{21}$

a. Akta itu harus dibuat oleh (door) atau dihadapan (ten overstaan) seorang pejabat umum;

b. Akta itu harus dibuat dalam bentuk yang ditentukan oleh undang-undang;

c. Pejabat umum oleh atau dihadapan siapa akta itu dibuat harus mempunyai wewenang untuk membuat akta tersebut;

SKMHT yang dibuat dalam bentuk akta notaris harus memenuhi ketentuan Pasal 1868 KUHPerdata, Pasal 38 UUJNP, dan Pasal 15 UUHT. Terpenuhinya syarat-syarat keotentikan akta yang ditentukan dalam ketiga peraturan tersebut maka SKMHT berbentuk akta notaris dapat digolongkan sebagai akta otentik.

Mengacu pada akta PPAT yang dibuat berdasarkan lampiran Perkaban 8/2012, apabila dikaji mengenai keotentikannya berdasarkan Pasal 1868 KUHPerdata maka akta PPAT tersebut dinyatakan bukan akta otentik. Dikatakan demikian karena, Pasal 1868 KUHPerdata menyatakan bahwa akta otentik adalah akta yang dibuat oleh atau dihadapan seorang pejabat umum, yang mana akta tersebut harus dibuat dalam bentuk yang ditentukan oleh undang-undang, serta akta dibuat oleh atau dihadapan pejabat umum yang mempunyai wewenang untuk itu.

${ }^{21}$ Ibid, hal. 32. 
Sementara SKMHT dibuat dalam bentuk akta PPAT berdasarkan lampiran Perkaban 8/2012. Jadi, SKMHT tidak memenuhi salah satu syarat dari akta otentik yang ditentukan dalam Pasal 1868 KUHPerdata yaitu akta dibuat dalam bentuk yang ditentukan oleh undang-undang karena SKMHT berbentuk akta PPAT bentuknya ditentukan oleh Perkaban 8/2012 yang tidak setara dengan undang-undang.

Berdasarkan uraian diatas, maka SKMHT dalam bentuk akta notaris harus memenuhi syarat sebagaimana yang disebutkan dalam Pasal 1868 KUHPerdata, Pasal 38 UUJNP, dan Pasal 15 ayat (1) UUHT. Dengan demikian SKMHT merupakan akta yang dibuat oleh atau dihadapan notaris sebagai akta otentik yang mempunyai kekuatan pembuktian yang sempurna. Sedangkan SKMHT dalam bentuk akta PPAT tidak memenuhi syarat akta otentik sebagaimana yang tercantum dalam Pasal 1868 KUHPerdata, khususnya mengenai unsur akta PPAT yang dibuat tidak berdasarkan undangundang, tetapi hanya aturan hukum setingkat Peraturan Pemerintah atau Peraturan Menteri. Dengan demikian akta PPAT bukan sebagai akta otentik melainkan sebagai perjanjian biasa setingkat dengan akta dibawah tangan.

\subsection{Bentuk SKMHT Setelah Dikeluarkannya Perkaban 8/2012}

Dikeluarkannya Perkaban 8/2012 harus diapresiasi tinggi oleh notaris maupun PPAT berikut dengan lampiran Perkaban beserta reformasi birokrasinya. Dengan dikeluarkannya Perkaban 8/2012 ini, PPAT tidak lagi sebagai pengisi blangko akta, tetapi sudah berfungsi sebagai pembuat akta.
Dalam prakteknya masih terjadi kesimpangsiuran dan ketidakseragaman mengenai bentuk SKMHT. Sepanjang masih didalam kewenangan wilayah kerja PPAT, maka SKMHT dibuat sesuai dengan lampiran Perkaban 8/2012 tersebut. Apabila objek hak tanggungan berada diluar kewenangan PPAT maka SKMHT harus dibuat dalam bentuk akta notaris dengan penomoran notaris sepanjang berada dalam wilayah kewenangan notaris sebagaimana dinyatakan dalam Pasal 17 ayat (1) huruf a UUJNP yang menyatakan bahwa "notaris dilarang menjalankan jabatan diluar wilayah jabatannya."

$$
\text { Menurut Syafran Sofyan, }
$$

Notaris/PPAT/Pejabat Lelang di Jakarta Selatan dalam Majalah Renvoi Nomor: 12.120.X tertanggal 03 Mei 2013 menyatakan bahwa "SKMHT yang dibuat dalam bentuk akta notaris diperkenankan dan SKMHT diperkenankan dibuat dalam bentuk minuta." 22 Sehubungan dengan hal tersebut sesuai dengan UUJN, membuat akta dalam bentuk originali adalah pengecualian.

Syafran Sofyan menyatakan pula "SKMHT diatur dalam Pasal 15 ayat (1) jo Penjelasan Umum angka (7) UUHT, SKMHT wajib dibuat dalam bentuk akta otentik, dalam hal ini akta notaris atau akta PPAT. Hal ini merupakan Bestaansvoorwaarde, untuk itu SKMHT wajib dibuat dengan akta notaris atau akta PPAT yang merupakan akta otentik sesuai dengan Pasal 1868 KUHPerdata."23 Disamping itu, dengan berlakunya Perkaban 8/2012 maka tata cara

${ }^{22}$ Syafran Sofyan, 2013, Surat Kuasa Membebankan Hak Tanggungan (SKMHT) Setelah Berlakunya Perkaban No. 8 Tahun 2012, Renvoi Nomor: 12.120.X, tanggal 03 Mei 2013, hal. 82 .

${ }^{23}$ Ibid. 
pembuatan dan bentuk SKMHT harus memenuhi ketentuan yang ditetapkan dalam Perkaban tersebut, khususnya SKMHT dalam bentuk akta PPAT.

Setelah berlakunya Perkaban 8/2012 ditentukan bentuk akta PPAT sesuai dengan lampiran Perkaban tersebut termasuk salah satunya SKMHT. Berlakunya Perkaban 8/2012 tidak meniadakan SKMHT dalam bentuk akta notaris sebagaimana diatur dalam Pasal 15 ayat (1) UUHT. Berdasarkan teori penjenjangan norma dan asas lex superiori derogate legi inferiori, pada dasarnya peraturan perundang-undangan yang tingkatannya lebih tinggi mengalahkan peraturan perundangundangan yang lebih rendah. Berkaitan dengan teori dan asas tersebut maka Perkaban 8/2012 tidak dapat meniadakan Pasal 15 ayat (1) UUHT. Pasal 15 ayat (1) yang menentukan SKMHT dapat dibuat dalam 2 (dua) bentuk yaitu akta notaris dan akta PPAT tetap berlaku. SKMHT dalam bentuk akta notaris wajib memenuhi ketentuan Pasal 1868 KUHPerdata, Pasal 38 UUJNP, dan Pasal 15 UUHT sedangkan SKMHT dalam bentuk akta PPAT wajib dibuat sesuai dengan ketentuan Perkaban 8/2012.

\section{AKIBAT HUKUM SURAT KUASA MEMBEBANKAN \\ TANGGUNGA N \\ HA K \\ BENTUK AKTA NOTARIS SETELAH DIKELUARKANNYA PERATURAN KEPALA BADAN PERTANAHAN NASIONAL $\begin{array}{llll}\text { NOMOR } & 8 & \text { TAHUN } & 2012\end{array}$ TENTANG KETENTUAN PELAKSANAAN PERATURAN PEMERINTAH NOMOR 24 TAHUN 1997 TENTANG PENDAFTARAN TANAH}

\subsection{Kewenangan Notaris Dalam Membuat SKMHT}

Wewenang atau yang sering pula ditulis dengan kewenangan merupakan suatu tindakan hukum yang diatur dan diberikan kepada suatu jabatan berdasarkan peraturan perundangundangan yang berlaku yang mengatur jabatan yang bersangkutan. Hukum administrasi negara mengenal wewenang dapat diperoleh secara atribusi, delegasi, atau mandat. Wewenang secara atribusi adalah pemberian wewenang yang baru kepada suatu jabatan berdasarkan suatu peraturan perundang-undangan atau aturan hukum. Selanjutnya, wewenang secara delegasi merupakan pemindahan atau pengalihan wewenang yang ada berdasarkan suatu peraturan perundang-undangan atau aturan hukum. Sedangkan mandat bukan merupakan pengalihan atau pemindahan wewenang, tetapi karena yang berkompeten atau berwenang berhalangan. ${ }^{24}$

Berdasarkan UUJN, notaris sebagai pejabat umum memperoleh wewenang secara atribusi, karena wewenang tersebut diciptakan, diberikan dan diperoleh dari UUJN itu sendiri. Jadi, wewenang yang diperoleh notaris bukan berasal dari lembaga lain, misalnya dari Departemen Hukum dan Hak Asasi Manusia RI.

Kewenangan notaris diatur dalam Pasal 15 UUJNP dibagi menjadi tiga kewenangan meliputi kewenangan umum, kewenagan khusus, dan kewenangan notaris yang ditentukan kemudian. Kewenangan notaris untuk membuat SKMHT didasari pada ketentuan Pasal 15 ayat (1) UUHT. Ketentuan pasal tersebut menegaskan bahwa SKMHT dapat dibuat dalam dua bentuk yaitu akta notaris atau akta PPAT. Selanjutnya berdasarkan Pasal 15 ayat (1) UUJNP menegaskan bahwa notaris berwenang membuat akta otentik mengenai semua perbuatan, perjanjian, dan penetapan yang diharuskan oleh peraturan perundang-undangan dan/atau yang

${ }^{24}$ Habib Adjie, 2011, $\underline{\text { Hukum Notaris }}$ Indonesia, Tafsir Tematik Terhadap UU No. 30 Tahun 2004 Tentang Jabatan Notaris, PT. Refika Aditama, Bandung hal. 78. 
dikehendaki oleh yang berkepentingan untuk dinyatakan dalam akta otentik, menjamin kepastian tanggal pembuatan akta, menyimpan akta, memberikan grosse, salinan dan kutipan akta, semuanya itu sepanjang pembuatan akta itu tidak juga ditugaskan atau dikecualikan kepada pejabat lain atau orang lain yang ditetapkan oleh undang-undang.

Konsekuensi logis dari ketentuan Pasal 15 ayat (1) UUHT adalah pejabat yang berwenang membuat SKMHT dengan akta notaris adalah notaris yang dalam menjalankan jabatannya tunduk pada tata cara bentuk sesuai dengan ketentuan UUJN. Ketentuan pasal tersebut menegaskan pula notaris berwenang untuk membuat akta otentik. Berkaitan dengan itu, SKMHT merupakan suatu surat kuasa yang dibuat oleh pemberi kuasa kepada penerima kuasa untuk membebankan hak tanggungan atas objek hak tanggungan yang dijadikan jaminan kredit.

Berdasarkan ketentuan Pasal 1868 KUHPerdata, Pasal 1869 KUHPerdata, Pasal 15 UUJNP dan Pasal 38 UUJNP, apabila notaris membuat SKMHT dengan mempergunakan format SKMHT sesuai dengan Perkaban 8/2012, maka SKMHT tersebut tidak dapat diperlakukan sebagai akta notaris. Notaris sebaiknya membuat SKMHT dalam bentuk akta notaris dengan menggunakan Akta Membebankan Hak Tanggungan (AKMHT) yang memenuhi ketentuan yang tercantum dalam Pasal 38 UUJNP. Karena berdasarkan Pasal 15 ayat (1) UUJNP, notaris berwenang untuk membuat akta otentik bukan surat seperti halnya SKMHT dan SKMHT dalam format Perkaban 8/2012 belum memenuhi ketentuan mengenai akta otentik sebagaimana diatur dalam Pasal 1868 KUHPerdata dan Pasal 38 UUJNP.

3.2 Akibat Hukum SKMHT Dalam Bentuk Akta Notaris Setelah Dikeluarkannya Perkaban 8/2012
Sebagaimana yang telah dijelaskan diatas, SKMHT dalam bentuk akta notaris untuk dapat dinyatakan sebagai akta otentik harus memenuhi ketentuan Pasal 1868 KUHPerdata, Pasal 38 UUJNP, dan Pasal 15 UUHT. Mengenai kekuatan pembuktian akta otentik diatur dalam Pasal 1870 KUHPerdata yang menyatakan bahwa "suatu akta otentik memberikan diantara para pihak beserta ahli waris-ahli warisnya atau orang yang mendapat hak dari mereka, suatu bukti yang sempurna tentang apa yang dimuat didalamnya."25

Selanjutnya, berdasarkan Pasal 1869 KUHPerdata dinyatakan bahwa "suatu akta, karena tidak berkuasa atau tidak cakapnya pegawai dimaksud diatas, atau karena suatu cacat dalam bentuknya, tidak dapat diperlakukan sebagai akta otentik, namun demikian mempunyai kekuatan sebagai tulisan dibawah tangan jika ia ditandatangani oleh para pihak." Apabila Pasal 1 ayat (7) UUJNP dikaitkan dengan Pasal 1869 KUHPerdata maka apabila akta notaris tidak sesuai dengan bentuk yang ditetapkan oleh undang-undang dapat diartikan cacat dalam bentuknya, sehingga akta notaris tersebut tidak dapat dikatakan sebagai akta otentik namun hanya memiliki kekuatan pembuktian dibawah tangan jika ditandatangani oleh para pihak.

Jadi, apabila SKMHT berbentuk akta notaris dibuat sesuai dengan lampiran Perkaban 8/2012 maka SKMHT tidak dapat digolongkan sebagai akta otentik karena tidak memenuhi ketentuan Pasal 1868 KUHPerdata dan Pasal 38 UUJNP sehingga kedudukannya hanya sebagai akta dibawah tangan. Sedangkan apabila SKMHT berbentuk akta notaris dibuat sesuai dengan ketentuan Pasal 38 UUJN maka menurut hemat penulis SKMHT dibuat dengan judul Akta Kuasa Membebankan Hak Tanggungan

(AKMHT) karena kewenangan notaris adalah membuat akta otentik berdasarkan Pasal 15 ayat (1) UUJNP.

${ }^{25}$ Subekti dan Tjitrosudio, 1980, Kamus Hukum, Pradnya Paramita, Bandung, hal. 475. 
IV. PENUTUP

\subsection{Simpulan}

6.1.1 Perkaban $8 / 2012$ tidak meniadakan bentuk Surat Kuasa Membebankan Hak Tanggungan dalam bentuk akta notaris sebagaimana diatur dalam Pasal 15 ayat (1) UUHT. SKMHT dalam bentuk akta notaris wajib dibuat sesuai dengan ketentuan Pasal 1868 KUHPerdata, Pasal 38 UUJNP, dan Pasal 15 UUHT sedangkan SKMHT dalam bentuk akta PPAT wajib dibuat berdasarkan Perkaban 8/2012 beserta lampirannya

6.1.2 Akibat hukum yang timbul apabila SKMHT dibuat dalam bentuk akta notaris setelah dikeluarkannya Perkaban 8/2012 yaitu :

- Apabila SKMHT berbentuk akta notaris dibuat sesuai dengan lampiran Perkaban 8/2012 maka SKMHT tidak dapat digolongkan sebagai akta otentik karena tidak memenuhi ketentuan Pasal 1868 KUHPerdata dan Pasal 38 UUJNP sehingga kedudukannya hanya sebagai akta dibawah tangan.

- Apabila SKMHT berbentuk akta notaris dibuat sesuai dengan ketentuan Pasal 38 UUJN maka menurut hemat penulis SKMHT dibuat dengan judul Akta Kuasa Membebankan Hak Tanggungan (AKMHT) karena kewenangan notaris adalah membuat akta otentik berdasarkan Pasal 15 ayat (1) UUJNP.

\subsection{Saran}

4.2.1 Diharapkan Badan Pertanahan Nasional menentukan bahwa notaris berwenang dalam membuat SKMHT tanpa harus mengikuti ketentuan yang diatur dalam Perkaban 8/2012, karena Pasal 15 ayat (1) UUHT menyatakan dengan tegas bahwa SKMHT dapat dibuat dalam 2 (dua) bentuk akta notaris atau akta PPAT.

Diharapkan pemerintah mengeluarkan peraturan perundangundangan yang mengatur mengenai SKMHT dalam bentuk akta notaris sehingga terciptanya kepastian hukum mengenai bentuk akta SKMHT dan dalam praktek notaris/PPAT tercipta keseragaman bentuk akta SKMHT dalam bentuk akta notaris.

\section{DAFTAR PUSTAKA}

\section{Buku-Buku}

Adjie, Habib, 2009, Meneropong Khazanah Notaris dan PPAT Indonesia (Kumpulan Tulisan Tentang Notaris dan PPAT, PT. Citra Aditya Bakti, Bandung.

, 2011, Hukum Notaris Indonesia, Tafsir Tematik Terhadap UU No. 30 Tahun 2004 Tentang Jabatan Notaris, PT. Refika Aditama, Bandung.

Ali, Zainuddin, 2010, Metode Penelitian Hukum, Sinar Grafika Offset, Jakarta.

Amiruddin dan Zainal Asikin, 2004, Pengantar Metode Penelitian Hukum, PT. Rajagrafindo Persada, Jakarta.

Andreae, S. J. Fockema, 1951, Pechtsgeleerd Hand woorddenboek, diterkemahkan oleh Walter Siregar, Bij J.B. Wolter Uitgeversmaat Schappij, N. V. Gronogen, Jakarta.

Arif, M. Isa, 1978, Pembuktian \& Daluwarsa, Intermasa, Jakarta. 
Dewi, Santia dan R.M. Fauwas Diradja, 2011, Panduan Teori \& Praktik Notaris, Pustaka Yustisia, Yogyakarta.

Harsono, Budi, 2008, Hukum Agraria Indonesia, Sejarah Pembentukan Undang Undang Pokok Agraria, Isi dan Pelaksanaannya Jilid 1 Hukum Tanah Nasional, Djambatan, Jakarta.

Mertokusumo, Sudikno, 1979, Hukum Acara Perdata di Indonesia, Liberty, Yogyakarta.

Mustofa, 2010, Tuntutan Pembuatan Akta-Akta PPAT, Karya Media, Yogyakarta.

Salim H.S., 2001, Perkembangan Hukum Jaminan di Indonesia, Raja Grafindo Persada, Jakarta.

Subekti dan Tjitrosoedibio, 1980, Kamus Hukum, Pradnya Paramita, Jakarta.

Sumaryono, Eugenius, 1987, Filsafat Hukum Sebuah Pengantar Singkat, Universitas Atmajaya Yogyakarta, Yogyakarta.

Surakhmad, Winarno, 1972, Pengantar Penelitian Ilmiah, Dasar Metode dan Teknik, Tarsito, Bandung.

Sutedi, Adrian, 2008, Peralihan Hak Atas Tanah, PT. Sinar Grafika, Jakarta.

Titik Triwulan Tutik, 2011, Kontruksi Hukum Tata Negara Indonesia Pasca Amandemen UUD 1945, Kencana Prenada Media Group, Jakarta.

Widjaya, I.G. Rai, 2002, Merancang Suatu Kontrak Contract Drafting, Kesaint Blanc, Bekasi Timur.

\section{Artikel}

Syafran Sofyan, 2013, Surat Kuasa Membebankan Hak Tanggungan (SKMHT) Setelah Berlakunya Perkaban No. 8 Tahun 2012, Renvoi Nomor: 12.120.X, tanggal 03 Mei 2013. 